\title{
Teacher's Voice And Student Interpersonal Attractiveness
}

\author{
Gumgum Gumelar ${ }^{1}$, Erni K.A Gilipanda ${ }^{2}$ \\ \{ggumelar@unj.ac.id ${ }^{1}$, erni.gilipanda@yahoo.co.id ${ }^{2}$ \} \\ Faculty of Psychology, Universitas Negeri Jakarta, Jakarta,, Indonesia ${ }^{1,2}$
}

\begin{abstract}
Student's perception of attractiveness of their teacher's appearance does not only come from the external performances such as the face or cloth, which are visible to visual senses, but also from the voice heard by the learners, which will bring out the particular perception on how they see their teacher. This current study investigated whether the influence of the pitch of the teacher's voice influenced the perception of student's interpersonal attractiveness towards their teacher. This research used quota sampling technique and was designed by manipulating the pitch of the male and female voices to rank their attractiveness from the participant. The result from this study was indicated that teacher's voice pitches were related to their interpersonal attractiveness.
\end{abstract}

Keywords: Voice Pitch, Interpersonal Attractiveness, Student-Teacher's relationship.

\section{Introduction}

Education is the process of forming intellectual and emotional skills to be able beneficial for nature and others. Basically, humans are born as living beings who have the sense to think. In line with the opinion of John Dewey that education is the most important thing for humans to be able to continue to hone and develop the ability possessed. Education can be obtained from the family environment, school environment, and community environment.

When it comes to education, it is closely related to a teacher and a student. Teacher has a variety of roles in teaching and educating students, teacher's diverse roles in teaching and learning processes - teacher as collector, initiator, facilitator, mentor, demonstrator, classroom manager, mediator, supervisor and elevator, teacher also has a variety of important tasks and roles, teacher plays a role as the second parent after the parent at home and the task of teacher as a profession that demands to develop the professionalism of self, according to the development of science and technology [1].

Albeit, student's interest in each teacher in terms of appearance is certainly influenced by the perception of each student. This is supported by the opinion of Berry and Hansen (1996) which stated that one of the things affecting interest in a person is the perception. Perception is someone's impression or judgment of others [2]. Yufiarti and Gumelar (2013) stated that perception is a process by the organism in interpreting and organizing sensations to produce a meaningful experience [3]. 
Perception, in this case, is pursed on the interpersonal perception which one of them is influenced by the appearance or physical attractiveness. This assumption suggests that the perception of interpersonal interest as a simplified picture of conclusions about others (interaction between teacher and student or between student and teacher). Interpersonal interest is among other considerations of a person in building the relationship with others, in addition to personality and other aspects, the outward appearance that can be perceived by the senses altered the perception that formed in a person about others. Individual interpersonal interest is an attitude about others, in which social psychology believes that it contains the evaluation mechanism. In other words, someone will make a positive evaluation when they feel positive and makes a negative evaluation if feels negative [4].

As social beings, humans have the need to interact with others and used it as a way to understanding others, which is an important field in the discussion of educational psychology. There are several studies that highlighting the importance of interpersonal interest and interpersonal attraction toward the successful learning processes in class.

Like for example the classic study of Lott and Lott (1965) showed that the interpersonal attraction has positively influenced student academic achievement, where pupils tends to learn faster when they were working with the people they loved [5]. Once the interpersonal attraction between students and teacher is developed, they will have better chances to establish a positive communication in a class. As a result, this effective communication can support the effectiveness of learning and teaching processes.

The perception of the teacher's physical attractiveness is not only seen from the face or something that visually engaging, but, the voice heard by the student also raises certain judgments. Voice as an acoustic signal produced by human consists of various aspects. Based on research that has been done, the aspect that most influence someone's perception is voice pitch [6]. Voice pitch is formed from the vibrations produced by a person's vocal cords, where the vocal cords result from hormones produced within the body. In the learning process, the voice of the teacher, which is also known as the language of the teacher, has an important role of successful teaching process. Voice is the main element that teacher must have because a teacher must be a good communicator by having the skills to speak so that the process of transferring information can be worked thoroughly and the learning material can be accepted by students very well [7].

According to Pisanski and Rendall (2011) tone of voice is fundamental for perception process. They suggest that voice pitch along with timbre are important elements in perceiving someone's conversation. Both elements are based on the fundamental frequency which is resulting the voice [8]. The fundamental frequency is the sum of the vocal cords vibration per second. This amount corresponds to the length and duration of the vocal cords. Someone who speaks with a rising tone, the vocal cords will thin out and shorten so does with the lower vocal as well. The fundamental frequency is usually measured in Hertz (Hz), Hz represents the number of periodic cycles per second. Pisanski and Rendall (2011) mentioned that the fundamental frequency associate with the perception of voice pitch in which determined by the speed of the vocal cords vibration. In other way, not only about frequency but also gender differences in perceive of voice attractiveness having role in human interactions [9]. According Vukovic et al., (2011) women who showed a particularly strong tendency to perceive feminine voices as more trustworthy. Its may be conclude that the gender from teacher pitch have a different attractiveness from students perceived [10].

The study about differences in the voice pitch that relates to the appearance of a teacher performance is limited. Therefore this research study intended to investigate whether a teacher's voice pitch performed by the teacher affects student's interpersonal interest. This 
research was conducted to elementary school students, with the age range of 7 to 12 years. The reason is at this age the student has reached the concrete operational stage where children can group or divide something into different rules or sub-rules and consider the relevance [7]. At this age, the child has one of the three major impulses that a child experiences at this age that is the mental drive to get into the world of concepts, interactions, thoughts, and symbols of adults and children at this age is required to develop attitudes against the institution or social group.

\section{Method}

This research was used quantitative research approach with the pre-experiment design. The study was performed through observing one major group and intervening throughout the study. There was no control group to compare with the experimental group [11]. The preexperimental design used was the One-Group Post Test Design.

Subjects in this study were students with the age range of 10-11 years in five elementary schools located at East Jakarta. The data processed with manipulation check in order to ensure that the stimulus familiarity of respondent is free from bias.

The Likert scale was used in the measurement of this research. The scale consists of statements based on the theory of interpersonal interest. According to Baron, R.A and Byrne, (2003) interest refers to the level of interpersonal likeliness to something, where it has an evaluation aspect that would come into either positive or negative evaluation, with a range from very like to very dislike. The reliability coefficient of all items with a total of 6 items was 0.835 .

The statistical test used the Repeated Measure Sphericity Assumption method to see the effect of the independent to dependent variables. The intervention used in this study was the manipulation of the recorded teacher's voice pitch using the PRAAT acoustic phonetic software with each recording manipulated by raising and lowering the pitch by $\pm 20 \mathrm{~Hz}(17-21$ $\mathrm{Hz})$. T Each record is manipulated by raising and lowering its pitch of $(17-20 \mathrm{~Hz})$. The process of sound manipulation was done by using the PRAAT acoustic phonetic software [12]. The manipulation should be compatible with the human auditory sense in general.

\section{Result and Discussion}

This study involved 150 participants where only data from 131 people which can be processed $(\mathrm{N}=131) .19$ participants withdraw due to recognizing the voice stimulus provided. This can bring the effect of subjectivity which could further influence the participants' perceptions of the given stimulus. Subjects aged 10 years with a percentage of $6.87 \%$ as many as 9 people, aged 11 years with a percentage of $73.28 \%$ of 96 people, and aged 12 years with a percentage of $19.85 \%$ as many as 26 people. 
To minimize bias in this study, the introduction of the stimulus from the manipulation to be used by using the question "do you recognize this voice before?" The answer to the subject that recognized the voice stimulus is biased because the voice stimulus will be associated with a characteristic of the foreknown teacher. Based on the manipulation check, it was found that $87.3 \%$ of participants $(\mathrm{N}=131)$ were eligible to continue the research process.

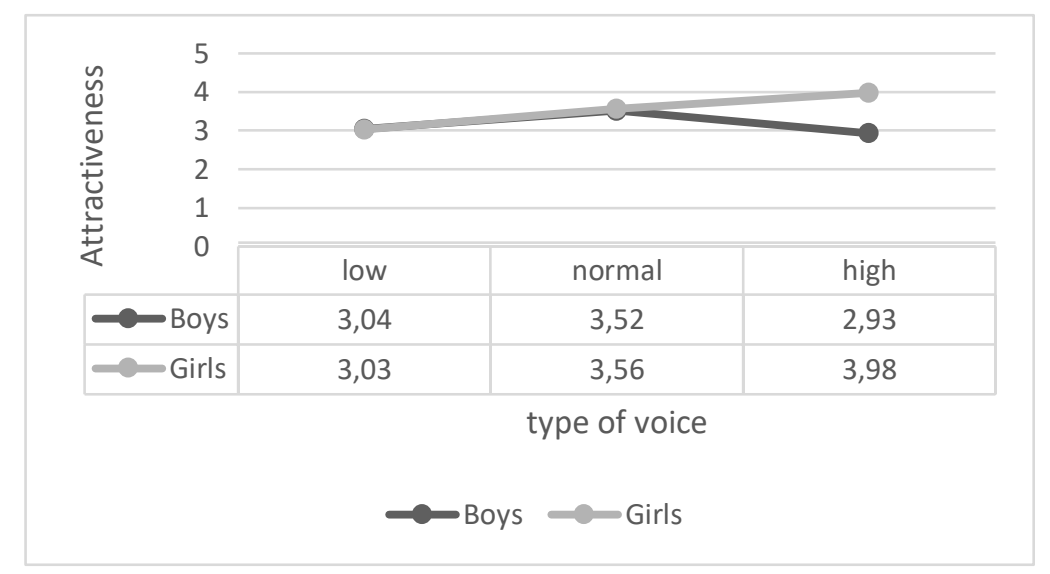

Fig. 1. Voice attractiveness among gender perspective.

Figure 1 shows the mean value of each variation of voice pitch that has been made with the female pitch variation is preferred over other 5 variations of voices. For the male voice pitch variation preferred normal voice pitch than low and high male voice pitch variations. The result shows that normal voice pitch was preferred over high and low voice pitch variations.

The following table is a result of the significance of mean scores comparison between variations using the Repeated Measure ANOVA technique.

Table 1. Repeated Measure Sphericity Assumption.

\begin{tabular}{ccc}
\hline Factor & F & Sig \\
\hline Voice Pitch & 29.777 & 0.000 \\
\hline
\end{tabular}

From the table presented above, could be seen that the result of statistical analysis of Sphericity Assumption resulting F score of 29.777 with a $p$ value of 0.000 . This result means that there was significance correlation, so it can be concluded that $p<\alpha$ which means alternative hypothesis (Ha) in this research was accepted while the null hypothesis (Ho) in this research was rejected. If used $\mathrm{F}$ table comparison $(1 ; 130)$ with $\mathrm{F}$ calculation, the result of $\mathrm{F}$ table was 3.91 so it can be expressed F count $>\mathrm{F}$ table. So it can be concluded from the data of $\mathrm{F}$ calculation that alternative hypothesis (Ha) was accepted and the null hypothesis (Ho) was rejected, thus there is a significant influence of voice pitch variable with interpersonal interest variable.

The perception of the teacher's physical attractiveness is not only seen from the face or something that is visible to the eyes, the voice heard by the student also raises certain 
judgments. Voice as an acoustic signal produced by humans consists of various aspects. Based on the research that has been done, the aspect that most influence someone's perception is voice pitch [6]. Voice is a component of the physical morphology that determines human's interest, thus the voice pitch heard by the students might raises particular judgments.

Teacher should have a nice and engaging appearance, particularly in managing the voice while teaching to ensure their student paying the attention and further enhanced learning efficiency. In accordance with the previous research in which stated that students' achievement is strongly influenced by two factors one of the factors is the external factor that is the appearance that can influence student's interest and motivation, so this research proves that there is influence between the teaching performance of civics education teacher toward student motivation.

In this current study, the attractiveness of the teacher is sourced from its voice and the results of this study suggest the voice of the teacher influences interpersonal interest. In addition, this study is also in line with the theory that a qualified teacher is the one who runs the job professionally. In other words, to master a good pedagogic competence, teacher must also have good yet clear voices, by not too fast or slow and varied [13]. In accordance with the research, students prefer medium voice pitch than voice pitch that sounds fast or slow. This is consistent with the theory that the basic skills of teaching are not only competence and science but also of the ability of the teacher to provide his or her skills in teaching, and one of the skills that the teacher has belonged to is the skill in the voice variation in order to achieve the appropriate learning targets.

Voice is the important aspect which is used as the language of the teacher to communicate and deliver learning materials. Good voices have an impact on the achievement of understanding in students and can improve the school's ranking. This is in line with Cherepanova (2002) research which mentioned that one of the external images is the voice of the teacher that can improve the quality of education and the achievement of educational goals to improve the ranking of the school. One way to be a good or ideal teacher is to have an external image or good speaking skills as well.

Teacher should be a good communicator by mastering the ability to deliver their massages efficiently, particularly through their voice.

The use of teaching styles variations including voice can enhance and nurture students' attention to the relevance of teaching and learning process, improve students' learning atmosphere, and encourage as well as motivate children to learn, in this case the variations of voice that teacher can do in the form of intonation, tone, speed and volume [1]. Teacher's gestures do not only rely solely on the pedagogical competence, but also come from the external images and variations in teaching such as their voice. With all of this in teacher's hand, they will be able to establish a dynamic interaction, improve communication between teacher and students, and can attract students' attention to the teacher. This gesture will affect the outcomes that will be achieved by the students, if the students love the teacher, the teacher also likes the students and students try to learn the best will create a relationship between teacher and child, starting from the student's interest in the teacher.

\section{Conclusions}

From the several variations of voice pitch presented, the results show that normal male voice pitch was more attractive for students and the second place, normal voice pitch of the 
female also have an attraction when compared to the low or high pitches either in male or female students. Finally, it can be concluded that normal voice pitch both male and female have more attractiveness when compared with low and high voice pitch both in male or female voice. Referring to the research results and conclusions that have been elaborated can be proposed suggestions such as (a) the measurement of interpersonal interest can be expanded by comparing the two stimuli so that more visible preference characteristics are measured.

Acknowledgements. We thank to Herdiyan Maulana for assistance with academic writing technique, and Ratna Dyah Suryaratri for comments that greatly improved this article.

\section{References}

[1]S. Djamarah, Guru dan Anak Didik Interaksi Edukatif (Suatu Pendekatan Teoritis Psikologis). Jakarta: Rineka Cipta, 2005.

[2]D. S. Berry and J. S. Hansen, "Positive Affect, Negative Affect, and Social Interaction," J. Pers. Soc. Psychol., vol. 71, no. 4, pp. 796-809, 1996.

[3]G. Yufiarti; Gumelar, Sejarah dan Dasar-dasar Psikologi. Jakarta: Pusat Pengembangan Kemampuan Manusia (Center for Human Capacity Development), 2013.

[4]D. . Baron, R.A ; Byrne, Psikologi Sosial. Jakarta: Erlangga, 2003.

[5]A. J. Lott and B. E. Lott, "Group Cohesiveness As Interpersonal Attraction :," Psychol. Bull., 1965.

[6]M. Zuckerman and K. Miyake, "the Attractive Voice : W H a T Makes It So ?," Heal. (San Fr., vol. 17, no. 2, 1993.

[7]J. . Santrock, Psikologi Pendidikan (Edisi 5, Buku Ke-2). Jakarta: Salemba Humanika, 2014.

[8]K. Pisanski and D. Rendall, "The prioritization of voice fundamental frequency or formants in listeners' assessments of speaker size, masculinity, and attractiveness," J. Acoust. Soc. Am., vol. 129, no. 4, pp. 2201-2212, 2011.

[9]K. Leaderbrand et al., "The Effects of Voice Pitch on Attractiveness The Effects of Voice Pitch on Perceptions of Attractiveness: Do You Sound Hot or Not?," Winona State Univ. Psychol. Student J., 2008.

[10]J. Vukovic et al., "Variation in perceptions of physical dominance and trustworthiness predicts individual differences in the effect of relationship context on women's preferences for masculine pitch in men's voices," Br. J. Psychol., vol. 102, no. 1, pp. 37-48, 2011.

[11]J. W. Creswell, Research design: pendekatan kualitatif, kuantitatif, dan mixed. Yogyakarta: Pustaka Pelajar, 2010.

[12]D. Boersma, P. and Weenink, "Praat: doing phonetics by computer." 2010.

[13]V. N. Cherepanova, . "Lecture Course on Image Ology: Manual," Tyumen, 2002. 